\title{
11 Daunting choices in transreligious theology
}

\author{
A case study
}

Wesley J. Wildman with Jerry L. Martin

The transreligious theologian faces daunting choices. These choices are not between religions - because for transreligious theologians the relevant data, concepts, and methods are not restricted to those of a single tradition - but rather between theological possibilities that cut across the religions. Understanding this is a critical part of the answer to the appealingly practical question about how we might go about the difficult task of transreligious theology. To the end of such understanding, this chapter presents a case study to illustrate the way theological options cut across traditions, inviting us along a pathway into the territory of transreligious theology oriented more by conceptual affinities and tensions than by religious identifications. ${ }^{1}$

Consider the category of ultimate reality, which fits postaxial religious traditions reasonably comfortably, and even many nonaxial traditions with tolerable awkwardness. This is a classic example of a vague comparative category: it has been specified with a variety of mutually incompatible models that exist side by side within traditions and recur in various modalities across traditions. ${ }^{2}$ Three of the most plausible, highly developed models of ultimate reality are an agential being (personal theism, or not-less-thanpersonal theism, where this divine being is the ultimate reality), the ground of being (beyond the categories of existence and nonbeing, and thus not a being but a principle that resists comprehensive understanding), and a subordinate god (a personal or not-less-than-personal God or gods within a more fundamental ultimate reality). Each ultimacy model boasts a long heritage, impressive explanatory power, significant cross-cultural visibility, and considerable internal diversity.

The agential being model supposes that, whatever else it may be, ultimate reality is a being aware of reality, responsive to events, and active within the world. Reality as whole is invested with personality and purpose, meaning and intelligibility, goodness and beauty. Every aspect of reality is rendered as coherent as the narrative of a focally aware and purposefully active personal life. No theory of ultimate reality is better fitted to the human tendency to see intentionality in events and to give group identity an authoritative focus.

Subordinate god models assert that there is at least one God, who is a being with determinate characteristics existing within a more fundamental 


\section{0}

reality. In this two-tiered view, God has the personal characteristics that make agential being models so appealing - providing existential meaning and a focus for community bonding - but the challenging task of providing an understanding of reality as a whole is addressed at a more abstract, impersonal level. Subordinate god models offer a way to avoid some of the conceptual stresses that beset agential being models.

Ground-of-being models make an ontological shift from God as a being to God as the ground or source of reality. This God is typically conceived as the source of being and nonbeing, and thus beyond those categories, which makes talk of existence or nonexistence unintelligible. To the extent that we can identify patterns and fundamental structures within the reality in which we live and move and have our being, we generate insights into the character of the ground of being but a full understanding always necessarily retreats from the grasping cognition of human beings, or indeed of any being whatsoever. This is why ground-of-being models are often expressed using apophatic strategies of indirection.

Consider a couple of examples of diversity internal to traditions. First, in the South Asian context, the theology of Rāmānuja (from the dvaita Vedānta tradition of Hindu philosophy) expresses personal theism. Rāmānuja's theology was formulated in explicit opposition to the advaita, or nondual Vedānta tradition, which belongs to the ground-of-being class of ultimacy models. Here we see a fundamental conflict internalized within the vague category of ultimate reality and persistently debated within the rich Vedānta tradition. Meanwhile, next door in Persia, Zoroastrianism presented two non-ultimate Gods, one good and one evil, who jointly constitute ultimate reality. This subordinate-gods cosmological vision eliminates the moral paradoxes of a personal ultimate and the moral neutrality of a nonpersonal ultimate and with striking clarity calls upon each human being to choose a moral side.

Second, in the Western context, the ancient tradition of the Israelite religion, as it transformed into Judaism and early Christianity, gave powerful articulation to a subordinate-being model of ultimate reality. Here God is not ultimate reality, but rather a force for goodness and justice within a wider chaotic reality. Creation was understood as this God taming chaos to fashion an intelligible moral order. Within three centuries of its origins, Christianity had produced a new understanding of creation in which God creates from nothing, thereby making a personal being the ultimate reality, with all of the attendant theodicy problems. In the same environment, early Stoicism was propounding a ground-of-being model that also influenced Christianity as it sought to articulate the radical transcendence associated with its emerging view of God as ultimate reality itself, rather than as the religiously relevant component of ultimate reality.

These models are live options for the transreligous theologian, once their cross-cultural character is recognized, but only if the theologian is prepared to leave the complex beauty of a single familiar religious continent to sail 
the oceans seeking conceptual affinities and tensions among the world's religious ideas and practices. Even within the domain of comparative theology, not all theologians find that journey appealing and would rather root themselves in one religious continent and learn from one or more other traditions how to root themselves ever more deeply. Fair enough; there is room for many theological temperaments within comparative theology. But transreligious theology takes a different journey, tackling fundamental theological questions as they arise within the human species, in all of its cultural and religious diversity and biological and bodily givenness. That conception of transreligious theology guides this chapter's exploration of ultimate-reality models that cut across religious traditions and co-exist within each tradition.

Identifying the presence of the three models cutting across religious traditions helps to shape the choices before the transreligious theologian. Comparing those models is a critical component in making rational choices. One line of comparative analysis begins with the observation that the three models exemplify different approaches to managing the human reality of anthropomorphic cognition, whereby we make use of what we think we know best (human beings) to understand what we surely know least (ultimate reality). For at least the following three reasons, comparing ultimacy models in terms of the ways they embrace or resist anthropomorphism may be a good place for the transreligious theologian to focus inquiry.

First, anthropomorphism is prominent in theological traditions and widespread in popular devotion, so it is difficult to avoid. The world of religious symbolism is replete with anthropomorphic imagery that promotes spiritual engagement, and there need not be anything naive or excessive about it. Moreover, some philosophic models ascribe to ultimate reality characteristics that are derived from human experience, such as awareness, feelings, intentions, plans, and agency. Yet intellectuals also critique anthropomorphic conceptions of ultimate reality as profoundly misleading, so there is a rich array of material here for the transreligious theologian to engage and process. Second, a tradition rich in anthropomorphic images and stories may well be the departure point of a theologian raised in or attached to a theistic tradition. This makes anthropomorphic models of ultimate reality of immediate interest to many comparative and transreligious theologians. Third, from cognitive psychology and evolutionary biology, we have learned that anthropomorphic cognition appears to be something like a cognitive default, in the sense of the most natural, ready-to-hand way of thinking available for making sense of the world around us, including difficult-tointerpret aspects of that world. Unfortunately, cognitive defaults of all kinds, including this one, are prone to error. Human beings routinely project consciousness, agency, and purpose where there is none. Our tendency to misapply anthropomorphic cognition does not refute anthropomorphism, but it does raise a red flag that transreligious theologians should evaluate carefully. 


\section{2}

Anthropomorphism isn't a simple continuum, ranging from extreme to none. There are three relatively independent dimensions of theological anthropomorphism: intentionality, practicality, and narrativity. Intentionality is the degree to which the model attributes intentional action, consciousness, and purposes to an invisible being such as a deity. Practicality is the degree to which a model of ultimate reality has existential grip and relevance to the immediate concerns of people's lives. Narrativity is the degree to which the model supports rich traditions of story, legend, and miracles that provide meaning to people's lives and shared referents for a community.

Anthropomorphism can be stronger or weaker in relation to each of these three dimensions, and theologians have adopted a variety of positions opposing anthropomorphism here, employing it there. The variety of configurations possible seems to offer the theologian considerable freedom, but the choice is meaningfully constrained. Each dimension can be tested against relevant information from cognitive science, evolutionary psychology, comparative religion, and other sources. The theologian may have to balance what best reflects the scientific data against what most effectively provides existential orientation and a sense of religious community. Then a complex theological hypothesis will have to be tested against explanatory standards, including applicability, adequacy, coherence, consistency, and pragmatic considerations such as ethical consequences, aesthetic quality, social potency, and spiritual appeal. Framing and ranking the relevant criteria are themselves theological choices.

Because choices that fit well with one criterion may fit poorly with another, the theologian should expect difficult decisions and conceptual stresses. For example, the ground-of-being model may be appealing to those who give great weight to evolutionary psychology and cognitive science, but may be found to be spiritually disappointing to those who sense that only a personal deity could be spiritually satisfying. The agential-being model may provide accessible spiritual understanding but struggle with scientific information about the ways human minds work. If the theologian finds the notion of providential action compelling, then God simply has to be an agent, but then the agential-being model must confront the problem of theodicy which arises from the equation of the personal God, who contains no evil, with comprehensive reality, which does. Theodicy can be a problem also for those ground-of-being models that regard God as unambiguously good. Theodicy is not a problem for subordinate-deity models, such as process theology or Zoroastrianism, which can divorce God from the moral flaws of reality as a whole and thereby protect God's moral perfection.

The theologian will also face anthropomorphically inflected metaphysical questions about the ultimate conditions for reality. These include the problem of the One and the Many, the problem of evil, the problem of ontological dependence, the problem of causal closure, the problem of the intelligibility of reality, and so on. For example, suppose the theologian faces a choice between 1 ) the hypothesis of God as omnipotent creator (this could 
be either an agential-being or a ground-of-being position, depending on the details) and 2) the hypothesis of cosmic moral dualism famous from classical Manichaeism and Zoroastrianism (this belongs to the class of subordinatedeity models). How might the theologian reason about such a choice?

It would be relevant to consider how well each handles such theological issues as the problem of evil and the problem of the One and the Many. The theologian will find that absolute moral dualisms handle the problem of evil spectacularly well, at least in one obvious sense: the origin of both good and evil is cosmological, there is no perplexing question of one deriving from the other, and there is no possibility of eschatological consummation in favor of one or the other. By contrast, omnipotent creator theism offers a famously contorted solution to the problem of evil, with evil explained either as a mere privation of good in a good world created by a good God, or as spontaneously derived from the good and tolerated by a good God for a good reason, or as deliberately created by a good God for a good reason (which eschatology may reveal), or as rooted in God's own morally ambivalent nature.

In regard to the problem of the One and the Many, the strengths and weakness of the two models are reversed. Absolute moral dualisms attribute everything in reality to two co-primordial creative forces locked in eternal battle, but don't explain why things are determined in that dualistic cosmological way, essentially dodging the problem of the One and the Many. Meanwhile, omnipotent creator theism traces all of determinate reality to the divine nature and its creative act. One famous solution to the problem of the One and the Many describes this divine creative act not as a taming of chaos or the forming of pre-existent material but as creation from nothing (ex nibilo), which implies that everything is ontologically dependent on this divine creator. The only limitation to this splendid solution to the problem of the One and the Many is explaining the determinate nature of God why should God be that way rather than some other way? Most ex nibilo creation traditions simply refuse to entertain that question, treating God as self-existent, and thus as the metaphysical backstop for all origins questions.

Thus, the model that solves one problem well does relatively poorly on the other. The transreligious theologian must ask: Is it more important to have an intelligible solution to the problem of evil or a compelling resolution of the problem of the One and the Many? Among those who would prefer to solve the problem of evil are Zoroaster, Confucius, and Alfred North Whitehead. Those who would prefer to solve the problem of the One and the Many include Plotinus, Śankara, and Robert Neville. Still others, with competing metaphysical intuitions (such as the later Augustine), regard the two problems as equally important.

How does one decide which problem is more pressing? Here the dimension of anthropomorphism we call practicality - the ready applicability of ideas to the immediate concerns of life - becomes a vital consideration. Prioritizing a solution to the problem of evil underwrites a way to think 
about one of the great problems of human life, in which we are often preoccupied with the pain and frustration of finitude and the outrage and needless suffering associated with moral evil. The more anthropomorphic position does not bother about completeness of rational intelligibility when it is not immediately relevant (which it rarely is in ordinary life). The less anthropomorphic position maximizes the completeness of rational intelligibility. Agential-being models rate high on the practicality dimension of anthropomorphism, responding to existential needs and spiritual yearnings, but they do little to resist error-prone cognitive defaults. An overemphasis on stories, myths, legends, and miracles may impair theological richness, complexity, sophistication, and validity. By contrast, the less anthropomorphic position prioritizes the completeness of rational intelligibility even if the result is a theological vision of ultimate reality that regular religious people find difficult to digest.

Several strategies are available to mitigate anthropomorphism. Consider the role of time and change within the life of an agential God. The more highly anthropomorphic models take their conceptual clues from narratives of God as an agent, which are amply present in the Vedas, the Hebrew Bible, the New Testament, and the Qur'an. In these narratives, God is a being who communicates, makes decisions, and acts at particular times. These characteristics require the divine version of a temporal consciousness and the metaphysical capacity to change, develop, and feel. On the other hand, the theologian may come to regard a temporal, changing being as either unsuitable for a deity or impossible for an omnipotent creator. These reservations struck Aquinas, Avicenna, and Maimonides for Abrahamic theisms, and Udayana for South Asian theism.

The attribution of eternity, immutability, and impassibility to God mitigates the intentionality dimension of anthropomorphism and draws the less highly anthropomorphic agential-being models close to the ground-of-being models. These attributions may help provide a rational account of comprehensive reality, but they may weaken the notion of a loving, benign, acting God vital to some religious understandings. Similarly, a God standing outside time may imply divine foreknowledge incompatible with human freedom and natural divine responsiveness. Here again, subordinate-deity models, which do not use God to explain ultimate reality, may be able to avoid these difficulties.

Like theologians rooted within a single tradition, the transreligious theologian may feel forced toward some balancing of the personal aspects of divinity and the impersonal aspects of ultimate reality. The medieval synthesis of classical theism combines personal (Biblical) and nonpersonal (philosophical) elements to define key doctrines such as the Trinity and the hypostatic union (the unity of humanity and divinity in Christ). In these formulations, the theologian grants the philosophers' point that ultimate reality is not a being, but construes this as "not a being like created beings," and then continues to insist with the Bible that the divine being is personal, 
intentional, and active. Where some analysts saw only contradictions in this synthesis, others saw hard-won harmony.

The clearest way to save the idea of God as agential being is to dispense with the claim that this God is the ultimate reality, which is to shift from the agential-being class to the subordinate-deity class. Process theologians have made exactly that move. The clearest way to save the idea of God as ultimate reality is to drop the claim that ultimate reality is an agential being, which is to shift from the agential-being class to the ground-of-being class of models. Some theologians, such as Paul Tillich and many Jewish postHolocaust thinkers, have done just that.

The transreligious theologian will also face the question of ontological dependence. The problem arises in classical theism when it asks how God can be truly omnipotent if there is something external to God with reference to which God's moral or ontological standing can be assessed? The doctrine of aseity or self-subsistence asserts that divine reality exists in, of, for, and from itself. This implies that all things - even the transcendental ideals of goodness, truth, and beauty - are ontologically dependent on God, derive from God, and are what they are because of God. The most austere form of aseity implies occasionalism, which is influential in Muslim theology: nothing occurs that God does not do, nothing is created that God does not create, and there is no causal continuity apart from the action of God to make causal patterns and regularities appear. Jewish, Christian, and Hindu theology tend to affirm aseity in a moderate form. The ex nibilo constraint ensures that nothing already exists alongside God when God creates, which is the constraint that process models of ultimate reality abandon. Thus, for the creation ex nibilo view, everything is ontologically dependent on God, and yet God is free to create as God sees fit, perhaps giving creation the power to sustain its own causal regularities.

A question that looms over all theological reasoning is: To what extent is ultimate reality to be regarded as generally fitting human modes of understanding? To what extent does ultimacy, by its very nature, exceed the grasp of finite knowers? If it exceeds too much, no knowledge and perhaps no relationship - at least no articulate relationship - to the divine is possible, as Aquinas argues in his discussion of analogy. If it fits too closely, the concept of God threatens to shrink to disturbingly human size. These issues are closely related to questions about religious language. To what degree are characteristics attributed to God literally and univocally? To what extent analogically or metaphorically or symbolically?

Symbolic interpretations shift reference away from the literal sense to some other meaning. Aquinas's doctrine of analogy offers an in-between view: God loves in a way that is analogous to the way human beings love - similar in respects sufficient to deserve the same word but different in respects appropriate to the difference between divine being and human being. Suitably reframed, divine agency can be retained even by groundof-being models. Tillich rejects virtually all literal statements about God, 
but compensates for the loss of concrete meaning with a vibrant theory of symbolism.

Ground-of-being models tend to rank relatively low on all three dimensions of anthropomorphism - significantly lower than the least anthropomorphic agential-being models - but versions differ in how they handle each of the three dimensions. For example, subordinate-deity models are an intriguing combination of high intentionality and high narrativity at the level of the depiction of the subordinate deity - higher than many agentialbeing models - and low intentionality and low narrativity at the level of ultimate reality as a whole, which is not religiously relevant for these models. Of course, what qualities to attribute to the God or gods operating under the dome of ultimate reality presents further decisions for the theologian, as well as how precisely to conceive the nature and structure of ultimate reality. However, the transreligious theologian may decide to resist all forms of anthropomorphism. This choice would lead to religious naturalism, with ultimate reality conceived as the relatively characterless God Beyond God.

Comparative religion gives rise to another criterion the transreligious theologian may find useful: deferring to the most sophisticated philosophical understandings in the various traditions as offering a kind of religious "expertise." Ground-of-being models fit well with the expertise criterion. They can accommodate a symbolic account of diverse religious ideas and frame a metaphysics in which every viewpoint finds a natural place, even if they are not all of equal value. The expertise criterion causes trouble for agential-being models, whose insistence on a personal highest being as ultimate reality tends to lock theology into the single religion focused on this particular God and to block the rich theological possibilities that take in the truths from multiple faiths, including the venerable nontheistic traditions.

The expertise criterion, giving emphasis to the rich diversity of religious ideas and practices, may point the transreligious theologian toward some form of pluralism. The presence of plural religious practices and multiple divinities probably inspired the Upanișads, with their affirmation that Brahman is One - behind, between, and beyond all, both identical with the human spirit and utterly transcending it, grounding and uniting everything that is. The same vision powers the perennial philosophy's attempt to coordinate all models of ultimate reality into a hierarchy perfectly suited to accommodate the vast range of spiritual personalities and inclinations, with each soul driving toward the loftier, transpersonal models as it commutes through the samsāric cycle of lives. ${ }^{3}$ A similar sensitivity to the perceived limits of religious images and ideas (images in conceptual form) inspires the apophatic declaration that ultimate reality is beyond all imagery and best met in linguistic indirection or even silence. Apophaticism is a strategy for speaking of ultimate reality by turning away from conceptual modeling, and indeed away from every kind of ultimacy speech - but all of this in such a way as to convey something indirectly about ultimate reality. There is a 
great deal to say, and much theoretical intricacy to negotiate, prior to lapsing into silence.

Whereas classical theism was always subject to conceptual stresses, the supposedly personal and nonpersonal elements of ultimate reality were more easily combined in past eras than they are now. The natural and social sciences have increased suspicions of the highly anthropomorphic default for human cognition. The sciences are most easily reconciled with naturalism, which either rejects all theological models as superstitions or invites new models based on the overflowing resources of nature itself, within which all human strivings, religious and otherwise, arise and find expression. Or, also compatible with the sciences, the response can be apophaticism, which finds the truest response to the divine, not in models, but in patterns of linguistic indirection that yield to a profound silence.

One of the challenges of transreligious theology is how to think theologically beyond a single tradition. What are one's materials, concepts, and guidelines? Fortunately, comparative religion and comparative theology have prepared an array of fruitful cross-cultural concepts, issues to be addressed, and theological options to consider. Theologians working beyond the walls now have ample resources for moving religious understanding forward.

\section{Notes}

1 With the help of Martin, this chapter reframes conceptual content from Wildman (2017) in a way designed to be helpful to transreligious theologians.

2 A properly vague comparative category is a key concept within the Cross-Cultural Comparative Religious Ideas project, the results of which are presented in three volumes edited by Robert Cummings Neville (2001).

3 For example, see Smith (1992).

\section{References}

Neville, Robert C. 2001. The Human Condition, Ultimate Realities, and Religious Truth. Albany, NY: SUNY Press.

Smith, Huston. 1992. Forgotten Truth: The Common Vision of the World's Religions. 2nd ed. San Francisco, CA: HarperOne.

Wildman, Wesley J. 2017. In Our Own Image: Anthropomorphism, Apophaticism, and Ultimacy. Oxford: Oxford University Press. doi:10.1093/oso/978019881 5990.003.0002 